\title{
Anna Halprin, Dancing Lifel Danser la vie Edited by Baptiste Andrien and Florence Corin
}

\section{Sally Gardner}

School of Communication and Creative Arts, Deakin University Burwood Campus 221 Burwood Hwy, Vic, Melbourne 3125, Australia. Email: sally.gardner@deakin.edu.au

In a recent interview published in Theatre, Dance and Performance Training Journal documentary writer and film-maker, Peter Hulton, talks about his work since the 1970s documenting the studio practices of performing artists and seminal performing arts teachers. ${ }^{1}$ Initially, Hulton observed practitioners at work and interviewed them, transcribing the interviews for publication as Arts Archives. ${ }^{2}$ He says that he 'was interested in the language of practitioners ... not only their struggle to find the language that for them was appropriate, but also the way their thoughts moved through their material as they commented upon it' (87). As the tools of documentation have changed and recording equipment has become more lightweight and discreet, Hulton has discovered that, visually, he can record a subtle range of embodied phenomena: 'the technology allowed you to relax into being there with the phenomenon that was revealing itself absolutely within the same time-line' (88).

Now Hulton has been involved with Baptiste Andrien and Florence Corin of Belgium's Contredanse organisation in the creation and publication of Anna Halprin, Dancing Life/Danser la vie - a bilingual document honouring the work of the American dancerartist-teacher, Anna Halprin. ${ }^{3}$ Anna Halprin, Dancing Life/Danser la vie comprises Hulton's recording of a workshop given by Halprin in Paris, 2010, and includes other documentary material which traces the long trajectory of her dance teaching and philosophy. The publication includes a booklet with 'Preface' (by Halprin); 'Editors' note'; and short 'Biography' of Halprin (by her husband, architect Lawrence Halprin). In conceiving the project, the editors have asked: 'what does the word dance mean to her?' For her part, Halprin states in the 'Preface' that the DVD 'describes my approach to dance in a way unlike any of the existing books and videos. ${ }^{4}$ It invites you inside one of my workshops, allowing you to absorb my teaching in action, and extends further to capture the whole spectrum of my approach'. She says that, in keeping with her own philosophy, Dancing Life/Danser la Vie 'closes the gap between art and life'.

Anna Halprin was influential in the emergence of American post-modern dance in 
the 1960s, providing an alternative vision of dance art to the one represented by the celebrated modern dancer-choreographers of the first part of the twentieth century in part, because she emphasised the need to study the objective structure of the body through anatomy. She was encouraged in this by the early twentieth century American dance teacher, Margaret D'Houbler with whom she studied. Anatomically-based 'body work', much of it developed by dancers or other individuals working close to dance (and, increasingly, including therapies such as Feldenkrais Awareness through Movement, Alexander Technique, BodyMind Centering), has been an important underpinning of dance performance practices ever since, providing dancers with the resources and tools for expanding and exercising their kinaesthetic imaginations. Certainly, a Western anatomical and kinesiological perspective on the body, sometimes combined with energetic conceptions of the body from Eastern anatomies, sustained many dancers' practices during that seminal period and up to today. In many ways, however, Halprin also carried on aspects of the philosophy of earlier modern dancers specifically Isadora Duncan (but also Martha Graham) who had, like her, been inspired by the natural environment of California towards a kind of 'pantheistic religion of the self' in which dance and life, the body and the world, would be one. ${ }^{5}$

The DVD Dancing Life/Danser la vie opens with Halprin, by now a woman of 91 years old, alone on a beach tip-toeing along the uneven, wavey edge of shadows cast on the sand by the coastal cliffs. She has a bird-like quality as she also hurries towards and backs away from the foamy edge of waves as they run up the shore. She is filmed both in close-up and from far away, and we thus see her as both a particular woman and as a representative human or universal figure. We hear her 'voice-over' espousing her philosophy of dance as a path to the self and as a way of connecting with the world and nature. It is a striking opening, as in the West the 'older woman' is a marginal figure, normally accorded little value. Here we see and hear her as a revered figure who embodies a singular vision.

The DVD contains a lot of material. It is organised by a number of digital icons that take the viewer to various groupings of documentary material: the 2 day Paris workshop presented as a number of discrete sections; a 'Roadmap' which includes interviews and archival material that give an insight into aspects of Halprin's dance practice, including her Movement Ritual, and what she calls the Movement/Feeling process; as well as a section on 'My Life and Art' which explores Halprin's work in its historical development and, influenced by her husband, the architect Lawrence Halprin, her use of scores for building events for large numbers of performers and later as participatory experiences.

This is a bilingual project. One striking experience for me was that, in clicking on the French version, I was able to hear both Halprin and a French translator, alternately, talking the listener through a 'relaxation exercise' (in the English version only Halprin speaks). On the screen we see only a band of vertical lines that lengthen and shorten to register the rhythm of stressed or accented syllables. The acoustic play between the two languages, so different from but intertwining one another, is a physical experience in itself, with the French sounds conveying almost by themselves the relaxing, tactile qualities of touch and breath.

Indeed voice is given a significant place in this document and is allowed to do its 
potential work of creating 'internal vibrations'. The singularity of Halprin's voice (which seems to have changed little over the years) with its confident tone in proposing and holding a physical experience for others is matched by Hulton's camera work during the Paris workshop. Hulton films human bodies as both subject matter and as their own frame. Here he has a lot to work with as the participants undertake the different workshop explorations under Halprin's guidance and gentle goading: they draw impressionistic images of themselves, lie and move on the floor of a vast hall, gently and robustly handle each other's bodies, weave through the space in and around one another as Halprin takes them through fundamental experiences of polarities (contract/release; active passive; up/down etc.) and much more. All these are ways of exploring how the body works physically, and how it can be available to each person for their own expressive purposes. Hulton is intimate but not intrusive or exposing in his camerawork. The workshop participants who are the objects of his gaze are neither self-consciously aware of it nor, however, does one sense that they are being made visible voyeuristically. He has the experience to be able to move towards a 'moment' with his frame and to allow it somehow to show itself, and he moves his gaze away sometimes in order to show less rather than too much.

In the 'Roadmap' section of this DVD, Halprin is seen working closer to therapy than to performing arts. Indeed, the Gestalt therapist Fritz Perls was influential for her. The documentary material here favours the later phases of her work where she turns towards participation rather than performance. Her 1967 work Parades and Changes, originally performed in Sweden, and banned in the USA because it involved nudity, is being redone now, but Halprin's better known work is probably the participatory events like Circle the Earth and Planetary Dance, which are scores for large groups and thus anticipatory of a current trend in Western ('participatory') art making. ${ }^{6} \mathrm{Of}$ particular interest in the 'Roadmap' is the section showing workshop participants and their drawn self-portraits. Halprin saw a link between the process of drawing and the kinaesthetic sense and vice versa. She felt that dancers needed to find themselves, to confront their self-image, in order to be individually creative as dancers or to grow as people. Drawing, she claims, helps to externalise and make available more objectively a person's own view of themselves and their own personal 'mythology' or meanings.

What are the implications of this publication? This is a contemporary form of document or archive that serves performance practices well if only the earlier material is available and there is someone with the sensibility of Peter Hulton to create new recordings. Often, the phases and modes of an artist's development, which are sometimes long and circuitous, can be very much misunderstood or unknown to audiences, particularly in the performing arts. Dancing Life/Danser la vie gives us a comprehensive view of Halprin's life and thought. The DVD encompasses contradiction and ambiguity: by watching different sections one can come to believe that Halprin's defining discourse and practice is one of self-psychology; that she has enormous knowledge of the body; that she is a dance evangelist, or that she initiated avant-garde currents of dance and performance. All of these are true and taken together they represent almost a century of practising dance, on her part.

Such documents as these can help to build literacy in an interested public or in a 
critical community. They do not substitute for the live experience of 'being there' in workshops with master practitioners. They do, however, help us to be able to keep tracing the connections between historical works and practices and current developments, not just intellectually but as those connections are embodied passed on through the oral traditions of dance and performance practices into the present and into the work of present generations.

\section{REFERENCES}

1 Peter Hulton (2014) 'Essai', Theatre, Dance and Performance Training, 5:1, 87-90, DOI: 10.1080/19443927.2014.896091.

2 Hulton's documentary work at this time was usually undertaken at Dartington College of Arts, Devon, UK (founded in 1961 and now part of Falmouth University), where numerous international theatre and dance practitioners have taught as invited guest artist-teachers. See Theatre Papers and 'Arts Archives' (www. arts-archives.org) 'an international digital moving image resource for performance research initiated by the Council of Europe'.

3 Contredanse is located at Maison du spectacle La Bellone, rue de Flandre 46, 1000 Bruxelles, Belgium or email: publications@contredanse.org.

4 These include the 2009 film: Breath Made Visible, directed by Ruedi Gerber. ZAS Film AG.

5 See Daly, Ann. (1995) Done Into Dance: Isadora Duncan in America. Bloomington and Indianopolis: Indiana UP, p. 11)

6 See for example Bishop, Claire. 2012 Artificial Hells: Participatory Art and the Politics of Spectatorship. London: Verso. 